Bangladesh J. Sci. Res. 29(1): 63-71, 2016 (June)

\title{
COMPARISON OF CLIMATIC VARIABLES AMONG DIFFERENT CLIMATIC SUB-REGIONS OF BANGLADESH
}

\author{
Md. Younus Mia*, Md. Ramjan Ali and Shimul Roy \\ Department of Environmental Science and Resource Management, \\ Mawlana Bhashani Science and Technology University, Santosh, \\ Tangail-1902, Bangladesh
}

\begin{abstract}
The study was conducted to compare the rate of change of selective climatic variables such as annual maximum and minimum temperature, annual total rainfall and annual average humidity among the three different climatic sub-regions (Western zone, northwestern zone and north-eastern zone) of Bangladesh. Annual averages of climatic parameters were calculated to analyze the trend lines, variation and change rate of climatic parameter during the study period. Five years moving average rainfall and humidity were also determined. It was observed that change rate of annual maximum temperature and annual average maximum temperature both were highest in north-eastern zone at the rate of 0.048 and $0.046^{\circ} \mathrm{C}$ per year, respectively. Highest annual minimum temperature change rate $\left(0.003^{\circ} \mathrm{C}\right.$ per year) was also found in the north-eastern zone but highest annual average minimum temperature change rate $\left(0.034^{\circ} \mathrm{C}\right.$ per year) was found in the north-western zone. Average annual rainfall was decreasing insignificantly in all the three climatic sub-regions whereas the highest change rate (21.50 mm per year) was observed in the north-eastern zone of Bangladesh. Highest annual average humidity change rate $(0.113 \%$ per year) was found in the north-western zone of Bangladesh and five years moving average of annual average humidity was increasing at the highest rate of $0.132 \%$ per year in the north-western zone of Bangladesh.
\end{abstract}

Key words: Climate change, temperature, rainfall, humidity

\section{Introduction}

Climate change represents one of the world's greatest human development challenges. The world is experiencing greater weather extremes, changes in rainfall patterns, heat and cold waves, and increasing droughts and floods and it has a negative impact on the environment and on people's lives and livelihoods (UNDP 2009). Climate change is resulting in the increased emission of the greenhouse gases reflecting variation in the climate statistics like temperature, precipitation and wind (Orindi and Eriksen 2005). Bangladesh has a humid, warm, tropical climate. Its climate is influenced primarily by monsoon and partly by pre-monsoon and post-monsoon circulations (Agrawala et al. 2003). Bangladesh is known as one of the most vulnerable countries under climate change. Bangladesh is one of the countries, which has been significantly affected by natural disasters. A recent study shows that at least 174 natural disasters affected Bangladesh from

*Author for correspondence: <mdmia1998@gmail.com>. 
1974 to 2003 (Sapir et al. 2004). Natural disasters are projected to increase due to expected changes in precipitation, recession of Himalayan glaciers, and sea level rise (Watson et al. 1998). Bangladesh is one of the disaster-prone countries around the world. Almost every year, the country experiences disasters of one kind or another such as tropical cyclones, storm surges, coastal erosion, floods, and droughts which results in loss of life and property as well as hindering the development activities (Ali 1999). Many parts of Bangladesh are directly or indirectly affected by the adverse impacts of climate change such as floods, riverbank erosion and cyclones, which ultimately destroy or damage people's livelihoods (Alam and Rabbani 2007). In the foreseeable future, Bangladesh is likely to be one of the most vulnerable countries of the world in the event of climate change. The global warming due to the increase in greenhouse gas concentrations in the earth's atmosphere and the consequent sea level rise are going to intensify the situation. Almost every sector of socio-economic life in Bangladesh is likely to be affected by climate change (Ali 1999). Different types of climatic hazards like floods, droughts, cyclones and its variability being experienced more frequently in Bangladesh than ever before due to climate change. Uncertainty of rainfall and uneven temporal and spatial distribution in one hand, creating flooding and on other hand longer dry spells evoking drought conditions (Lai et al. 1998).

In Bangladesh, such study has been done to analyze the pattern and trend of rainfall, temperature, solar radiation and relative humidity on different district, division and meteorological application on rice production, response of weather on wheat yield. But very few studies have been done to analyze climatic variables of the different climatic sub-regions as well as the comparison of climatic variables of the different climatic sub-regions of the country. However, the objectives of the present study were to assess the physical climatic variations (average annual maximum and minimum temperature, rainfall and humidity) as indicators of climate change and to compare the rate of change of the climatic variables among the three different sub-climatic zones (Western zone, North-western zone and North-eastern zone) of Bangladesh.

\section{Materials and Methods}

The study was conducted in the three climatic sub-regions (Western zone, North-western zone and North-eastern zone) of Bangladesh (Fig. 1). Western zone comprises greater Rajshahi district and parts of adjacent districts (Naogaon, Natore, Nawabganj and Joypurhat). This is the driest area in Bangladesh with rainfall generally below $1,500 \mathrm{~mm}$ and summer humidity of less than $50 \%$. Here maximum temperature is over $35^{\circ} \mathrm{C}$ and lowest $10^{\circ} \mathrm{C}$. North-western zone includes districts of Thakurgaon, Dinajpur, Rangpur, Gaibandha, Bogra, Sirajganj, Pabna, Kushtia and Meherpur. The annual rainfall is lower $(2536 \mathrm{~mm})$. Annual average highest temperature is $33.5^{\circ} \mathrm{C}$ and lowest $10.5^{\circ} \mathrm{C}$. North-eastern zone includes most of east and south Sylhet and a wedge shaped strip south of the Meghalaya Plateau. Here mean maximum temperature is rarely above $32^{\circ} \mathrm{C}$ but mean minimum is $10^{\circ} \mathrm{C}$ and below (Banglapedia 2008).

The study was carried out on the basis of secondary data analysis. Secondary data were collected from related authorities and institution, national and international journals, books, related 
reports, national encyclopedia of Bangladesh and from the internet. Climatic data were collected from Bangladesh Meteorological Department, Dhaka. Maps were collected from Banglapedia.

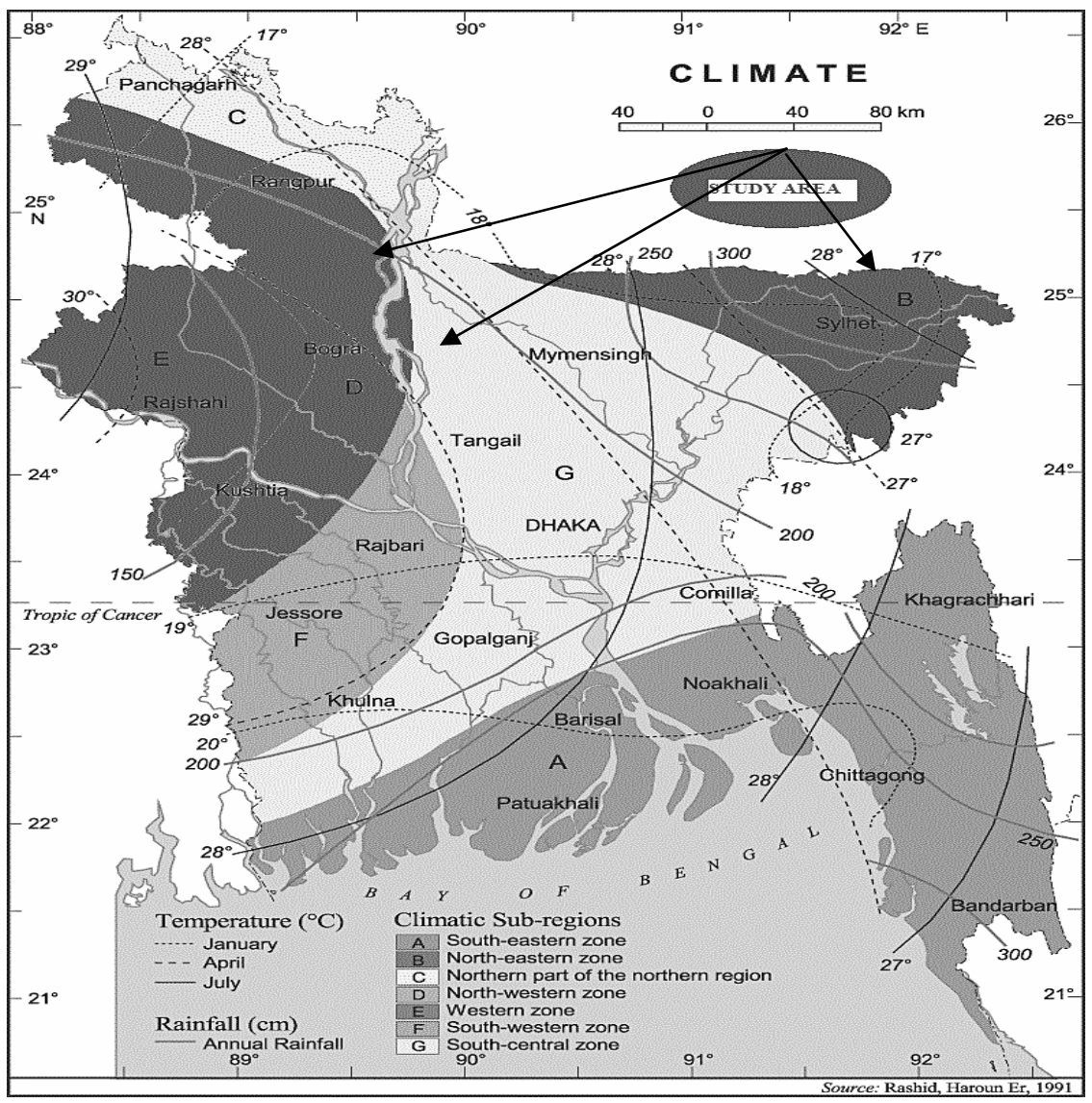

Fig.1. Map of Bangladesh showing the study area (Banglapedia 2008).

Data were compiled, tabulated and analyzed using MS excel for statistical analysis. Annual averages of climatic parameters (temperature, rainfall, and humidity) of different climatic subregions were calculated to analyze the variation and compare the rate of change of the climatic variables among these climatic sub-regions during 1981 to 2013 (33 years). The regression ( $\mathrm{R}^{2}$ ) was obtained through trends equation. One way of testing significance of the trends of the climatic parameters is calculating the coefficient of determinants of $\mathrm{R}^{2}$ of the trend. Highest correlation of the dataset can be found at 1 and it gradually reduces towards zero, value more than 0.5 has been considered as significant correlation. Five years moving averages were also determined because this reduces internal variation of data and helps to identify trends more strongly. 


\section{Results and Discussion}

Trend of annual maximum and minimum temperature of western zone of Bangladesh: The study revealed that annual maximum temperature for last 33 years of Western zone exhibited a decreasing trend at the rate of $0.032^{\circ} \mathrm{C}$ per year, which was not statistically significant $\left(\mathrm{R}^{2}=\right.$ 0.046). Interestingly, when the annual average maximum temperature for the same period was analyzed it was increasing at $0.011^{\circ} \mathrm{C}$ per year and this was also insignificant (Fig. 2). Ara et al. (2005) reported that the annual average temperature increased by $0.017^{\circ} \mathrm{C}$ per year over Rajshahi during the period of 1951-2001, which supports the findings (e.g. average annual maximum temperature trend) of this study.

From the study it was analyzed that, the trend of annual minimum temperature for last 33 years of Western zone was decreasing at the insignificant rate of $0.027^{\circ} \mathrm{C}$ per year but annual average minimum temperature for the same time period was increasing at $0.027^{\circ} \mathrm{C}$ per year which was also statistically insignificant $\left(\mathrm{R}^{2}=0.242\right)$ (Fig. 3).

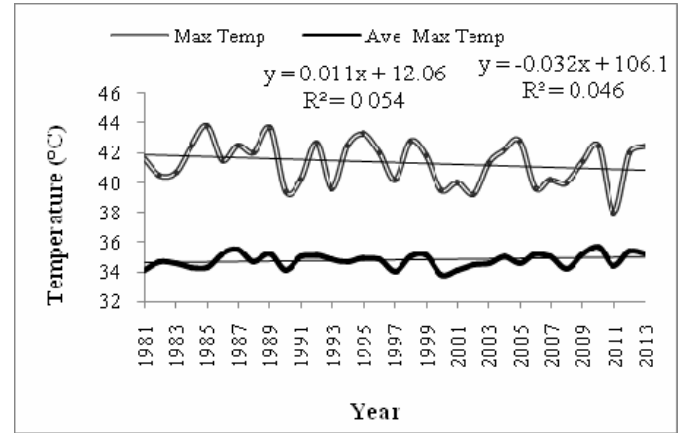

Fig. 2. Annual maximum and average maximum temperature of western zone of Bangladesh.

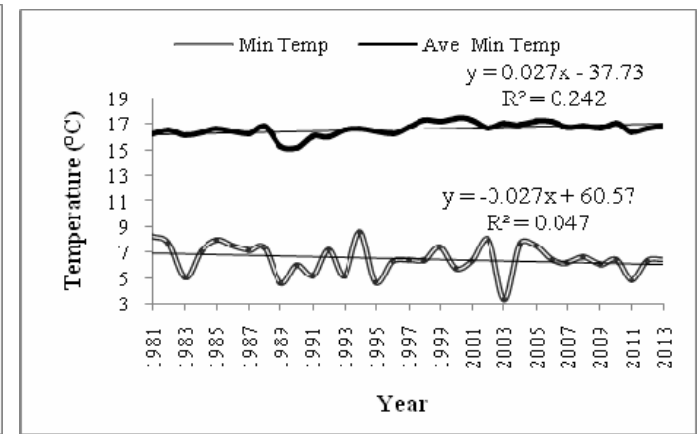

Fig. 3. Annual minimum temperature and average minimum temperature of western zone of Bangladesh.

Trend of annual total rainfall and annual average humidity of western zone of Bangladesh: It revealed from the results of the study that the annual total rainfall and 5 years moving average of annual total rainfall of Western zone both were in decreasing trend insignificantly at the rates of 14.28 and $12.40 \mathrm{~mm}$ per year, respectively (Fig. 4).

It is also apparent from the study that average humidity of Western zone for the study year was increasing at $0.089 \%$ per year and five years moving average annual average humidity was increasing at the rate of $0.12 \%$ per year, which was statistically significant (Fig. 5).

Trend of annual maximum and minimum temperature of North-western zone of Bangladesh: The study revealed that, annual maximum temperature for last 33 years (1981-2013) of Northwestern zone showed the decreasing trend at the rate of $0.019^{\circ} \mathrm{C}$, which was not statistically significant but annual average maximum temperature for same period was increasing at $0.014^{\circ} \mathrm{C}$ per year (Fig. 6). 
From the study it is revealed that, annual minimum temperature of North-western zone was decreasing at the rate of $0.016^{\circ} \mathrm{C}$, which was statistically insignificant $\left(\mathrm{R}^{2}=0.023\right)$ but annual average minimum temperature was increasing at the rate of $0.034^{\circ} \mathrm{C}$ per year, which was also statistically insignificant $\left(\mathrm{R}^{2}=0.267\right)$ (Fig. 7).
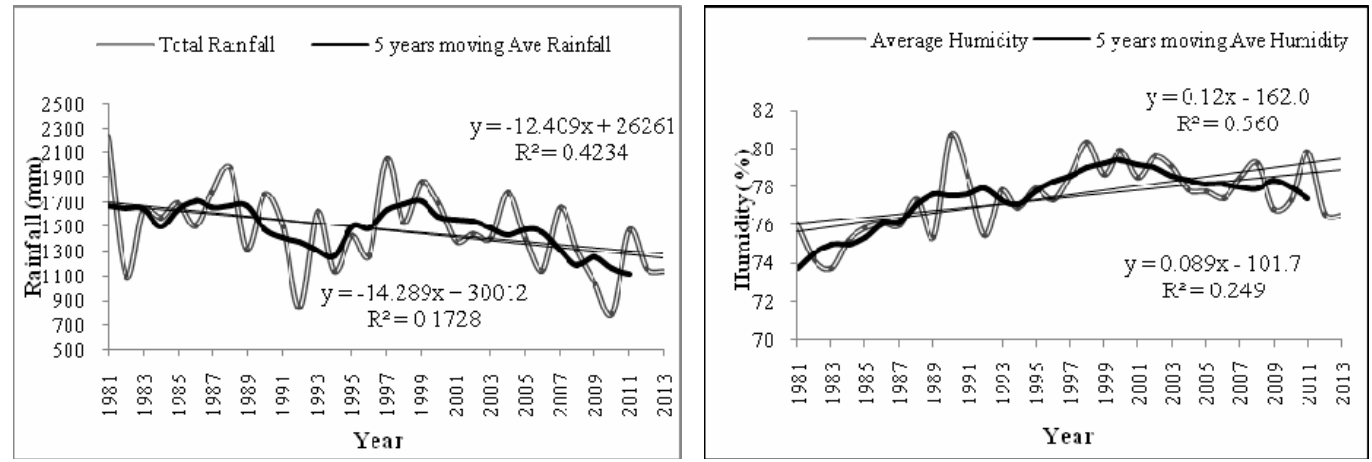

Fig. 4. Annual average rainfall and 5 years moving average of annual total rainfall of western zone of Bangladesh.

Fig. 5. Annual average humidity and 5 years moving average of annual average humidity of western zone of Bangladesh.

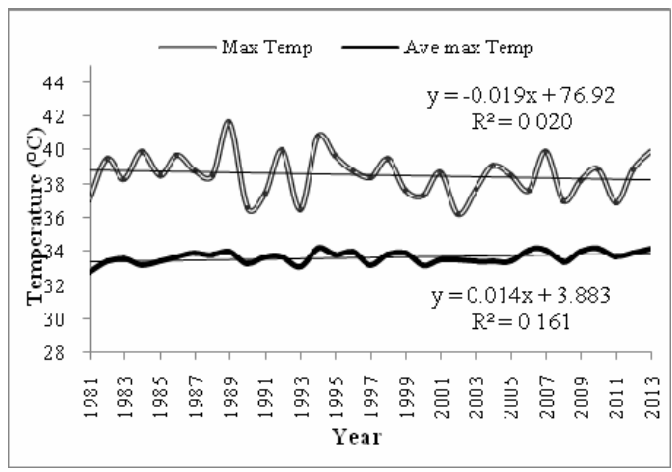

Fig. 6. Annual maximum and annual average maximum temperature of north-western zone of Bangladesh.

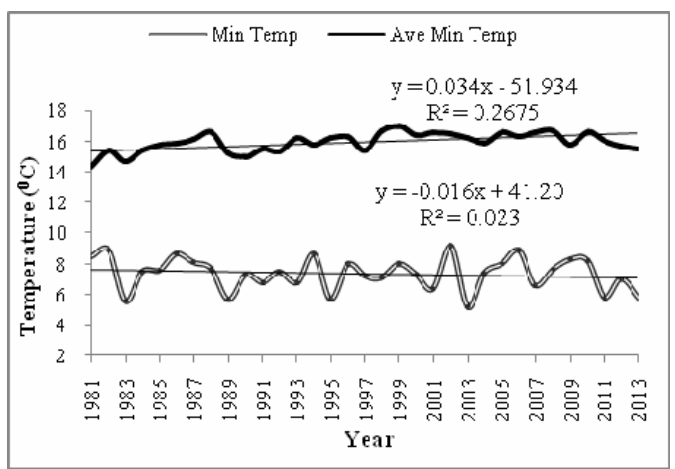

Fig. 7. Annual minimum and annual average minimum temperature of north-western zone of Bangladesh.

Trend of annual total rainfall and annual average humidity of North-western zone of Bangladesh: The study demonstrated that, the annual total rainfall and 5 years moving average of annual total rainfall both showed decreasing trends at the rates of 9.10 and $12.21 \mathrm{~mm}$ per year respectively (Fig. 8). The study conducted by Quadir et al. (2001) reported that the precipitation in Bangladesh has been decreasing during the recent decades, which supports the findings (e.g. annual total rainfall) of this study.

The study also revealed that, annual average humidity of North-western zone for the study year was increasing insignificantly at $0.113 \%$ per year and five years moving average of annual 
average humidity was also increasing insignificantly $\left(\mathrm{R}^{2}=0.45\right)$ at the rate of $0.132 \%$ per year (Fig. 9).

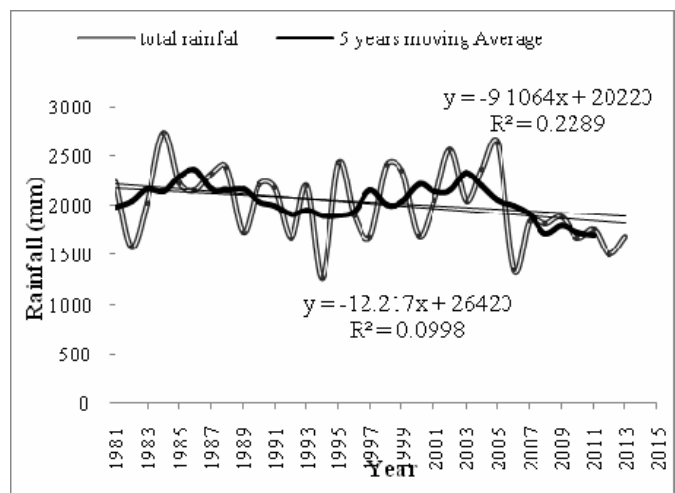

Fig. 8. Annual average rainfall and 5 years moving total of annual total rainfall of north-western zone of Bangladesh.

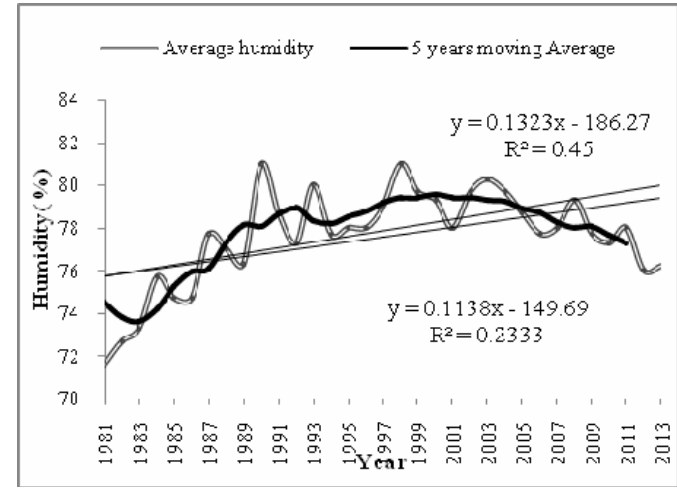

Fig. 9. Annual average humidity and 5 years moving average of humidity of north-western zone of Bangladesh.

Trend of annual maximum and minimum temperature of North-eastern zone of Bangladesh: In of North-eastern zone annual maximum temperature and annual average maximum temperature both were showing increasing trends and were increasing at the rate of $0.048^{\circ} \mathrm{C}$ and $0.046^{\circ} \mathrm{C}$ per year (Fig. 10).

From the study it is also apparent that annual minimum temperature for last 33 year of North eastern zone was increasing at the rate of $0.003^{\circ} \mathrm{C}$ per year and average minimum temperature for the same period was also increasing at the rate of $0.066^{\circ} \mathrm{C}$ per, which was not statistically significant (Fig. 11).

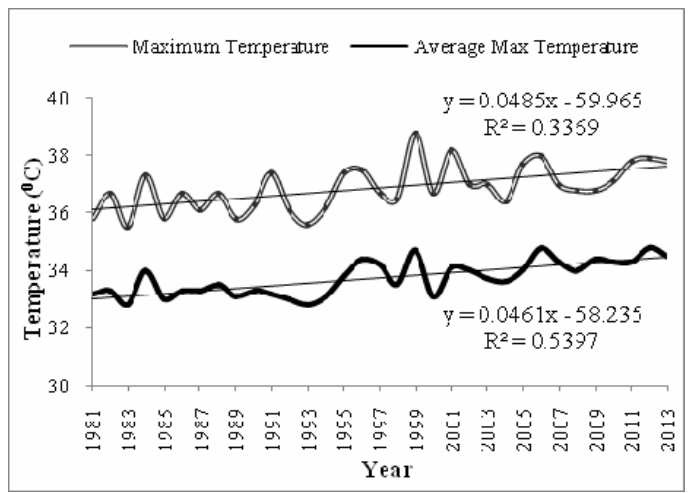

Fig. 10. Annual maximum and annual average maximum temperature of north-eastern zone of Bangladesh.

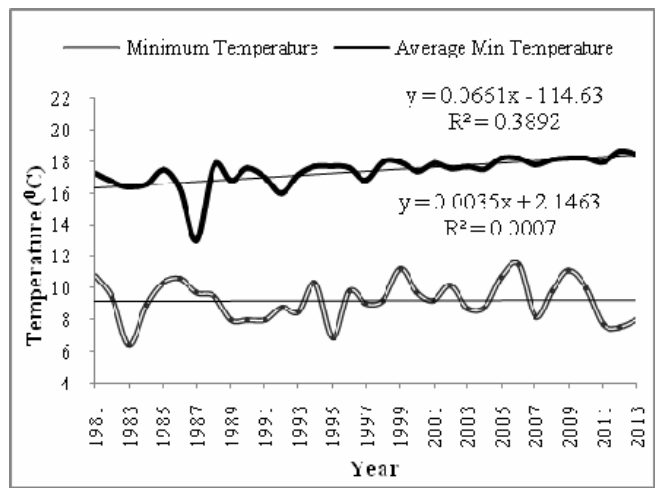

Fig. 11. Annual minimum and annual average minimum temperature of north-eastern zone of Bangladesh. 
Trend of annual total rainfall and annual average humidity of North-eastern zone of Bangladesh: From the figure it was clear that the trend of annual total rainfall and 5 years moving average of annual average rainfall of North-eastern zone both was decreasing at the rate of 21.50 $\mathrm{mm}$ and $23.95 \mathrm{~mm}$ per year respectively (Fig. 12).

When annual average humidity and 5 years moving average of annual average humidity for last 33 years of North-eastern zone were analyzed both had decreasing trends and were decreasing at the rates of 0.060 and $0.043 \%$ per year, which was not statistically significant (Fig. 13).

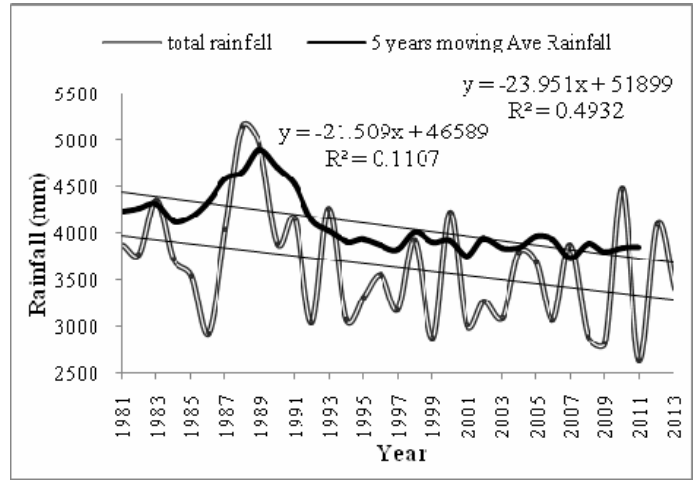

Fig.12. Annual average rainfall and 5 years moving total of annual average rainfall of north-eastern zone of Bangladesh.

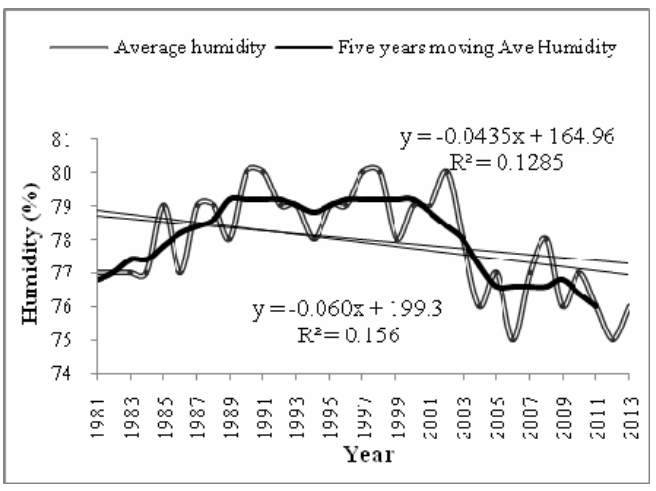

Fig.13. Average humidity and 5 years moving average of annual average humidity of north-eastern zone of Bangladesh.

\section{Comparison of climatic variables among different climatic sub-regions:}

Annual average maximum temperature has showed the increasing trends in all three selected climatic sub-regions. The change rate of increase of annual average maximum temperature were found $0.011^{\circ} \mathrm{C}, 0.014^{\circ} \mathrm{C}$ and $0.046^{\circ} \mathrm{C}$ per year over western zone, North-western zone and Northeastern zone respectively. Increasing trends of the annual average minimum temperature were also observed over Western zone, North-western zone and North-eastern zone at the rates of 0.027, 0.034 and $0.066^{\circ} \mathrm{C}$ per year, respectively (Table 1 ).

Table 1. Comparison of temperature among different climatic sub-regions of Bangladesh.

\begin{tabular}{lcc}
\hline $\begin{array}{l}\text { Name of climatic } \\
\text { sub-regions }\end{array}$ & $\begin{array}{r}\text { Average max. temperature } \\
\text { change rate }\left({ }^{\circ} \mathrm{C}\right)\end{array}$ & $\begin{array}{c}\text { Average min. temperature } \\
\text { change rate }\left({ }^{\circ} \mathrm{C}\right)\end{array}$ \\
\hline Western zone & +0.011 & +0.027 \\
North-western zone & +0.014 & +0.034 \\
North-eastern zone & +0.046 & +0.066 \\
\hline
\end{tabular}

It revealed from the result of the study that the annual total rainfall was found decreasing over Western zone, North-western zone and North-eastern zone at the rate of 14.28, 9.10 and $21.50 \mathrm{~mm}$ per year, respectively (Table 2). The increasing trend of annual average humidity was recorded in Western zone and North-western zone by 0.089 and $0.113 \%$ per year, respectively. But the 
decreasing trend of annual average humidity was recorded in North-eastern zone by $0.060 \%$ per year (Table 2).

From the overall analysis, it was revealed that annual average maximum temperature $\left(0.046^{\circ} \mathrm{C}\right.$ per year) (Table 1$)$ and annual total rainfall $(21.50 \mathrm{~mm}$ per year) (Table 2) change rate was highest in north-eastern zone among the three selected climatic sub-regions. But annual average humidity change rate was highest in north-western zone $(0.113 \%$ per year) and it was increasing (Table 2).

Table 2. Comparison of rainfall and humidity among different climatic sub-regions of Bangladesh.

\begin{tabular}{lcc}
\hline $\begin{array}{l}\text { Name of climatic } \\
\text { sub-regions }\end{array}$ & $\begin{array}{c}\text { Annual total rainfall } \\
\text { change rate }(\mathrm{mm})\end{array}$ & $\begin{array}{c}\text { Average humidity change } \\
\text { rate (\% per year) }\end{array}$ \\
\hline Western zone & -14.28 & +0.089 \\
North-western zone & -9.10 & +0.113 \\
North-eastern zone & -21.50 & -0.060 \\
\hline
\end{tabular}

In case of 5 years moving average of annual total rainfall for the study period, the highest decreasing change rate of average annual rainfall was observed as $23.95 \mathrm{~mm}$ per year in the northeastern zone of Bangladesh (Table 3).

The study also showed that 5 years moving average of annual average humidity was increasing in western zone and north-western zone but in North-eastern zone, annual average humidity was decreasing for the study period. Highest annual average humidity change rate (0.132\% per year) was found in North-western zone (Table 3).

Table 3. Comparison of 5 years moving average of rainfall and humidity among different climatic sub-regions of Bangladesh.

\begin{tabular}{lcc}
\hline $\begin{array}{l}\text { Name of climatic } \\
\text { sub-regions }\end{array}$ & $\begin{array}{c}\text { Total rainfall change rate } \\
(\mathrm{mm})\end{array}$ & $\begin{array}{c}\text { Average humidity change rate } \\
\text { (\% per year) }\end{array}$ \\
\hline Western zone & -12.40 & +0.120 \\
North-western zone & -12.21 & +0.132 \\
North-eastern zone & -23.95 & -0.043 \\
\hline
\end{tabular}

\section{Conclusion}

Climatic variability of western zone, north-western zone and north-eastern zone of Bangladesh has been found with changes in the trend of different climatic parameters particularly annual maximum temperature, annual minimum temperature, annual average rainfall and annual average humidity. Highest increasing rate of annual average maximum temperature was observed in the north-eastern zone of Bangladesh, which was $0.046^{\circ} \mathrm{C}$ per year. Increasing trends of the annual average minimum temperature were also observed over western zone, north-western zone and north-eastern zone at the rate of $0.027,0.034$ and $0.066^{\circ} \mathrm{C}$ per year, respectively. Highest annual total rainfall change rate $(21.50 \mathrm{~mm}$ per year) was also found in North-eastern zone of 
Bangladesh. But annual average humidity change rate was highest in north-western zone of Bangladesh (0.113 \% per year) and it was increasing. This study revealed that five years moving average of annual total rainfall decreasing rate was highest (23.95 mm per year) in North-eastern zone of Bangladesh and five years moving average of annual average humidity increasing rate was highest (0.132\% per year) in north-western zone of Bangladesh. However, the study also suggests some activities or programs to cope with the negative impacts arise due to climate change such as it is important to give special emphasize to the north-eastern zone to adapt with climate change related problem because climatic variables mainly temperature and rainfall is changing in this zone; policy decisions, scientific researches and institutional capacity building should be considered to handle and reduce the consequences of climate change impacts.

\section{References}

Agrawala, S., T. Ota, A.U. Ahmed, J. Smith and M.V. Aalst. 2003. Development and climate change in Bangladesh: Focus on coastal flooding and the Sundarbans. Organization for Economic Co-operation and Development (OECD), p. 11.

Ali, A. 1999. Climate change impacts and adaptation assessment in Bangladesh. Climate Research 12: 109-116.

Alam, M. and M.D.G. Rabbani. 2007. Vulnerabilities and responses to climate change for Dhaka. Environment and Urbanization 19(1): 81-97.

Ara, M., M.A. Hossain and M. M. Alam. 2005. Surface dry bulb temperature and its trend over Bangladesh, J. Bangladesh Agril. Sci. 29(1): 29-40.

Banglapedia. 2008. (National Encyclopedia of Bangladesh), Asiatic Society of Bangladesh. [Available online at]: http://www.banglapedia.org/ht/c_0347.htm (Accessed on January, 2014).

Lai, M., P.H. Whettori, A.B. Pittodi and B. Chakraborty. 1998. The greenhouse gas induced climate change over the Indian Sub-continent as projected by GCM model experiments. Terrestrial, Atmospheric and Oceanic Sciences, TAO 9(iv): 663-669.

Orindi, V.A. and S. Eriksen. 2005. Mainstreaming adaptation to climate change in the development process in Uganda. African Centre for Technology Studies 18(2): 16-23.

Quadir, D.A., M.L. Shrestha, T.M.A. Khan, F. Nazlee, M., Rahman and A.M. Mannan. 2001. The dynamic changes of climate in Bangladesh and the adjacent regions in association with global warming. Proc. International Conference of Mechanical Engineering, BUET, 26-28 December 2001, Dhaka Bangladesh, 30(2): 16-28.

Sapir, D.G., D. Hargitt and P. Hoyois. 2004. Thirty Years of Natural Disaster 1974-2003: The numbers. Centre for Research on the Epidemiology of Disasters. Universities the Lovain Press, Belgium, pp. 38-56.

United Nations Development Programme (UNDP). 2009. Linking Climate Change Policies to Human Development Analysis and Advocacy. A Guidance Note for Human Development Report Teams. Human Development Report Office. United Nations Development Programme. pp. 45-60.

Watson, R.T., M.C. Zinyoera and R.H. Moss. 1998. The Regional Impacts of Climate Change: An Assessment of Vulnerability. A Special Report of IPCC Working Group II. Cambridge: Cambridge University Press, p. 85.

(Manuscript received on 27 January, 2016; revised on 16 May, 2016) 